\title{
Dendrochronological study of the Canal del Roc Roig avalanche path: first results of the Aludex project in the Pyrenees*
}

\author{
Elena MUNTÁn,,${ }^{1,2}$ Laia ANDreU, ${ }^{1}$ Pere OLler, ${ }^{2}$ Emilia GUtí́r ReZ, ${ }^{1}$ Pere MARTíneZ ${ }^{2}$ \\ ${ }^{1}$ Departament d'Ecologia, Facultat de Biologia, Universitat de Barcelona, Av. Diagonal 645, ES-08028 Barcelona, Spain \\ E-mail: emuntan@icc.es \\ ${ }^{2}$ Institut Cartogràfic de Catalunya, Generalitat de Catalunya, Parc de Montjuïc, s/n, ES-08038 Barcelona, Spain
}

\begin{abstract}
Historical data about ancient avalanches are scarce in the Pyrenees. Dendrochronology can provide new data about past avalanches and their return period, but up to now little research has been carried out with this purpose. The Aludex project aims to obtain information about the frequency and extent of extreme avalanches, using a dendrochronological and a nivo-meteorological approach. In this paper, we present the results of a dendrochronological study of the Canal del Roc Roig avalanche path which was affected by two extreme avalanches in February 1996. This first dendrochronological study has permitted us to assess the tree-ring signals due to avalanche events in 53 out of 132 dated trees. The trees presented a variety of responses to the 1996 avalanche events. It is shown that the type of tree-ring signal depends on tree age. The methodology has proved successful in detecting the 1996 and 1972 documented avalanche events, and provided outstanding evidence of undocumented past events such as one in 1930.
\end{abstract}

\section{INTRODUCTION}

In February 1996 there was intense avalanche activity on the south face of the Pyrenees. Several extreme avalanches reached the subalpine Pinus uncinata forest which was seriously damaged downslope. Some buildings and roads were also destroyed. The oldest inhabitants could not recall such large avalanches, but was this in fact such an extraordinary event? Systematic avalanche data recording in the Catalan Pyrenees began in the 1980s; information before this date is scarce and inaccurate, and at present it is difficult to answer this question.

The Aludex project aims to use dendrochronology to find out when past avalanches occurred and their return period whenever possible, as well as to gather evidence for the meteorological conditions that cause catastrophic avalanche events in the Pyrenees. The information obtained by this project will contribute to a better understanding of these phenomena and will provide data that can be applied in dynamic avalanche models to determine avalanche hazard and risk.

Dendrochronology can provide information when meteorological and historical data are scarce or missing. In their annual rings, trees register the disturbances that have affected them in different ways. In other mountainous regions of the world, there are extensive dendrochronological studies on snow-avalanche paths (Potter, 1969; Shroder, 1978; Butler, 1979; Carrara, 1979; Johnson, 1987; Schweingru-

\footnotetext{
* Dedicated to Dr Richard Holmes for his huge contribution to dendrochronology.
}

ber, 1996; Pelfini and others, 2001), but there has been a lack of studies in the Pyrenees up to the present.

In this alpine range, the most widely distributed tree species growing at the highest elevations is Pinus uncinata (mountain pine) at altitudes of 1600 to $2300-2500 \mathrm{~m}$. At lower elevations, forests of Pinus sylvestris (Scotch pine) and Abies alba (silver fir) can be crossed by avalanche gullies. There are also forests of broad-leaved species, but our study site, Canal del Roc Roig, runs down a mountain pine forest and few other species are present.

Canal del Roc Roig was the first study site chosen because (i) it was disturbed by an extreme avalanche in 1996, (ii) trees growing there showed a wide range of growth forms, and (iii) the presence of old-growth trees provided past environmental data. Three different sampling strategies were used to determine which trees provide the most reliable signals of past avalanche events; we sought to use non-destructive methods whenever possible. The following results represent a pilot study for the design of the next field campaigns.

The main objective of this first research campaign at Canal del Roc Roig was to recognize tree-ring signals for future sampling sites. The known avalanches of 1996 were used to calibrate a set of dendrochronological methods to develop criteria for detecting past avalanche events.

\section{FEBRUARY 1996 EXTREME AVALANGHE EPISODE IN THE PYRENEES}

In February 1996 an extreme avalanche episode occurred that was the most important recently recorded in terms of its geographical extent, size and damaging effects. In this episode more than 70 avalanches were documented which 


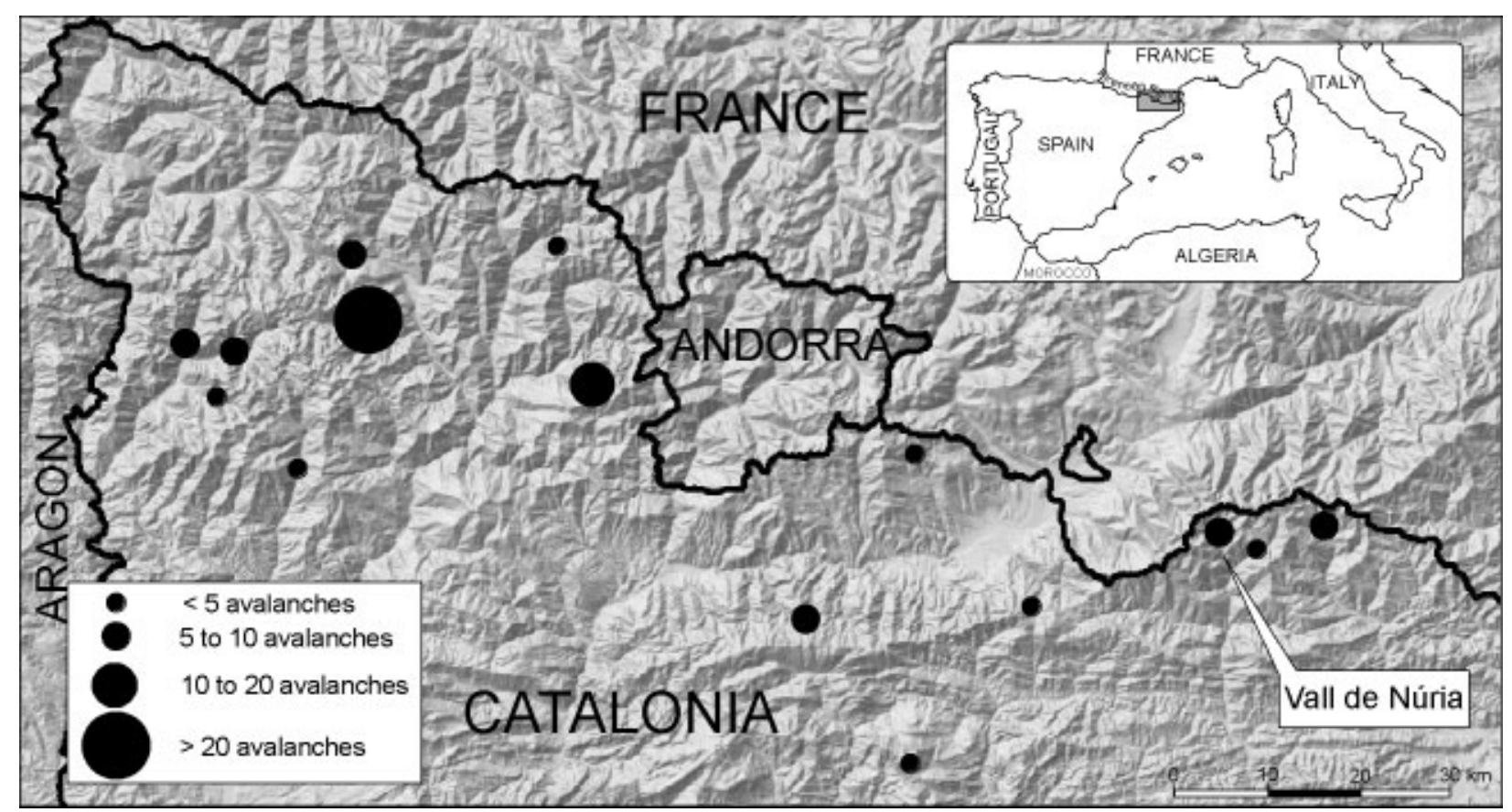

Fig. 1. Location of the Catalan Pyrenees and Vall de Núria. Circles indicate forest-damaging avalanches documented in the February 1996 episode.

destroyed forests from the eastern to the western part of the south face of the Catalan Pyrenees (Fig. 1). The exceptional nature of these avalanche events prompted the request for the Aludex project.

At the end of 1995 and beginning of 1996, weather conditions were characterized by low-pressure systems with south and east advections that caused heavy snowfalls which accumulated up to seven times the average precipitation in some sites (García and others, 2000). February began with a northerly advection and strong northwesterly winds. The combination of heavy snowfalls and strong northwesterly winds caused considerable snow accumulation, predominantly on southern and southeastern slopes. The surcharge of the drifted snow was responsible for the intense avalanche activity between 6 and 9 February 1996 in the Pyrenees.

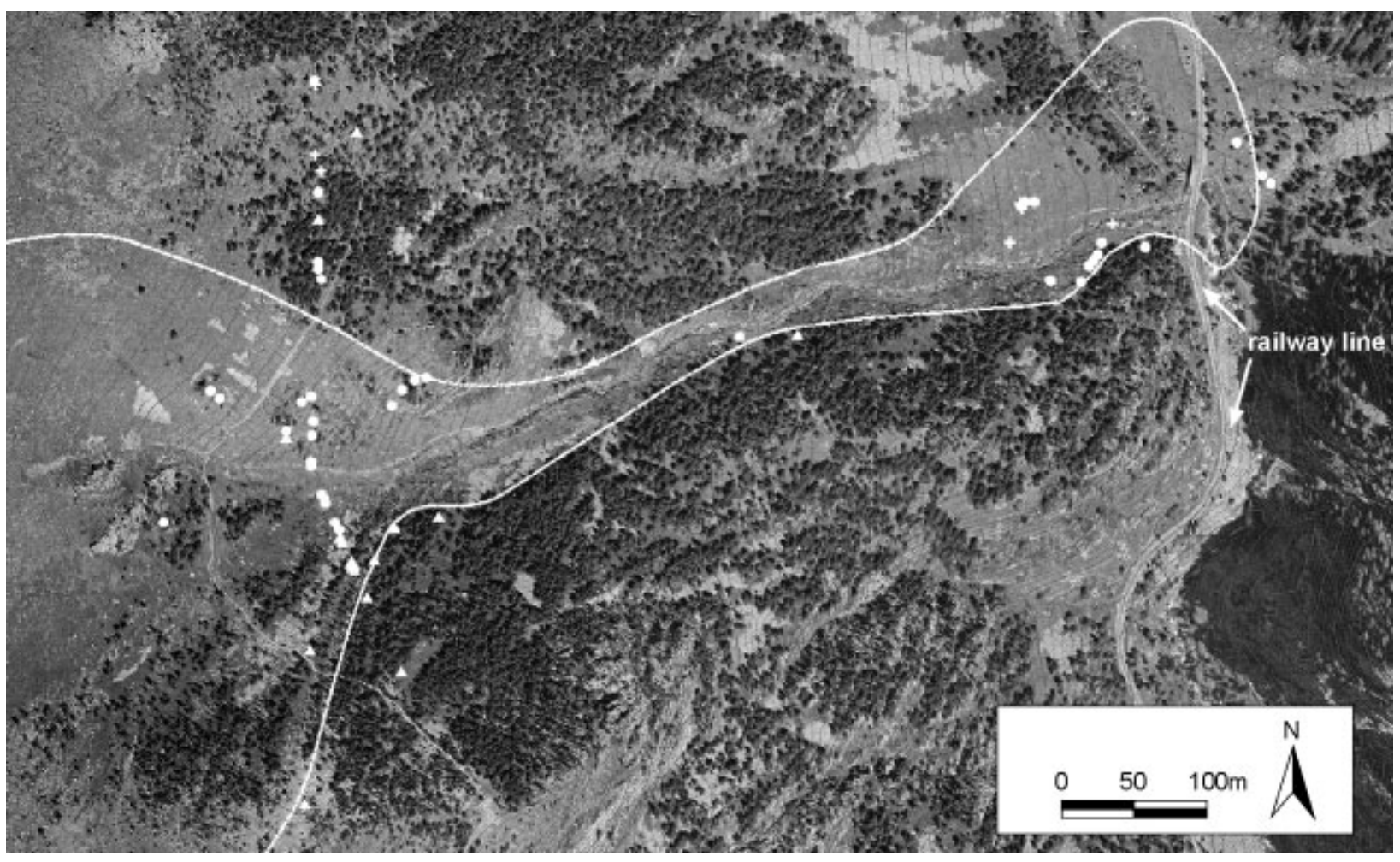

Fig. 2. Distribution of wounded trees from the 1996 and 1930 events. Circles: tree-ring signals on trees from 1996; triangles: signals on trees from 1930; crosses: signals from 1996 and 1930. White line: avalanche path determined from photo-interpretation and descriptive analyses. 


\section{STUDY SITE}

Vall de Núria is an historic tourist location with a small ski resort located at $1970 \mathrm{~m}$ a.s.l., in the eastern Pyrenees (Fig. 1). Access is by means of a rack railway, Cremallera de Núria, which climbs $1000 \mathrm{~m}$ over $12.5 \mathrm{~km}$ through a narrow valley, Gorges de Núria. Twenty-six locations along the railway line can be reached by avalanches (ICG, 2000). Between 6 and 9 February 1996, two great mixed (powder and dense-flow) avalanches (McClung and Schaerer, 1993) and other smaller ones reached the railway. One of these occurred at Canal del Roc Roig.

The Canal del Roc Roig avalanche-path starting zone is located at $2300 \mathrm{~m}$ a.s.l. on an open east-facing slope; the track zone is channelled from 2150 to $1850 \mathrm{~m}$ a.s.l.; at the run-out zone it becomes a dejection cone, and it reaches the Núria river at $1770 \mathrm{~m}$ a.s.l., climbing to the opposite slope (Fig. 2; see also Molina and others, 2004).

Three avalanches reaching the railway line have been recorded on the Canal del Roc Roig path since the line was inaugurated in 1931 (ICG, 2002). The first was in January 1972, and the other two were observed in February and March 1996. We know that the 1972 avalanche reached the railway and caused some damage, but the size and type of avalanche are unknown. The 1996 events are well documented and mapped. The first, a mixed avalanche on 7 February, reached the rack railway and Núria river and ran up the opposite slope to $1790 \mathrm{~m}$ a.s.l. The second, a wet-slab avalanche on 22 March, ran up the opposite slope to $1780 \mathrm{~m}$ a.s.l.

\section{METHODOLOGY}

\section{Field procedures}

In this pilot study, we used detailed scale orthophoto maps (Institut Cartogràfic de Catalunya, 1:5000 black-andwhite) to locate sampled sites and trees. These maps allowed good visualization of the zones and a better understanding of the processes by an exact localization of individuals in the area.

A total of 230 trees were sampled using different strategies at selected locations within the avalanche-affected area at Canal del Roc Roig.

1 Trees along two transects crossing the avalanche path were sampled to estimate the frequency of avalanche events in relation to the avalanche-path distance (this aspect is not dealt with in this paper). Each transect was $2 \mathrm{~m}$ wide, and all the trees were systematically sampled. One transect, $400 \mathrm{~m}$ long, was established in the upper part of the track at $2075 \mathrm{~m}$ a.s.l. measured at the centre of the gully; the second transect, $150 \mathrm{~m}$ long, was located near the run-out zone at $1785 \mathrm{~m}$ a.s.l.

2 Selected old pines growing in the downslope forest right edge were sampled to document the occurrence of ancient avalanches (Pelfini and others, 2001).

3 After inspecting the area, we sampled several zones where trees were more exposed to avalanche effects: at the arrival zone (see Molina and others, 2004), at the end of the track where most trees were dead (some of them transported), and in the centre of the gully path, above and below the upper transect.
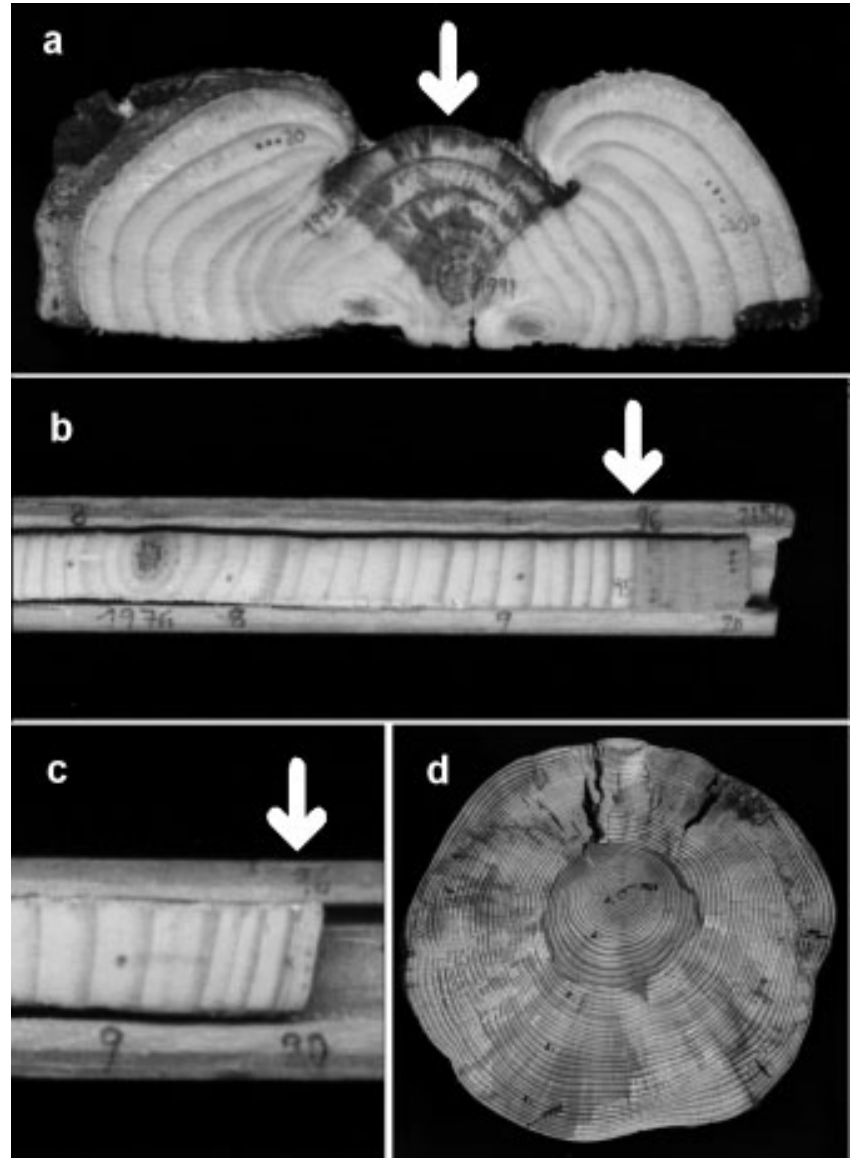

Fig. 3. Types of signals in 1996 tree-rings: ( a) wedge showing a scar, the dark coloration in the centre belonging to the secretion of resin and tannins; (b) compression wood in the last rings of the core, showing its dark coloration; (c) core with suppression growth in the last rings; (d) cross-section of a dead tree. Total number of sampled trees is 132 (109 trees were cored; cross-sections were taken from 18 dead trees, and wedges were sampled from 5 scarred trees).

From trees that were dead or wounded, trunk cross-sections and wedges, respectively, were sampled (Fig. 3). From living trees cores were preferred to cross-sections. Cores were sampled from $0.30 \mathrm{~m}$ height (basal cores) to $1.30 \mathrm{~m}$ from the base of the tree trunk (dbh (diameter at breast height) cores). To reduce tree damage, an attempt was made to sample scars with increment borers (two to three cores per scarred tree) and this proved useful. From each tree the following data were recorded: dbh, height, tree morphology, health, position in relation to the centre of the gully, and age by counting trunk internodes in young trees. Only part of this information is used in the present paper. We extracted wood samples from 132 mountain pines.

Out of the avalanche zone, a selection of old trees that were apparently not affected by avalanches was sampled to build a master chronology. An ancient pine, 400 years old, was found, but most of the pines were less than 200 years old. The reliable period was 125 years according to an expressed population signal (EPS) value of 0.85 (Cook and Kairiukstis, 1990). This chronology was used as a reference series to compare with the series from trees that had been damaged by snow avalanches, to date the year of death of dead trees, and to verify the dates of tree-ring signals. 


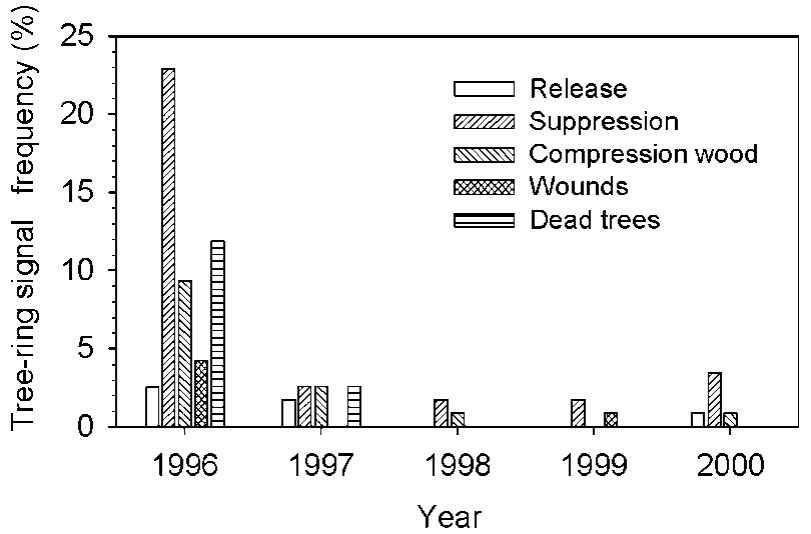

Fig. 4. Tree-ring signal frequency, 1996-2000. The different types of signals are shown for each year.

\section{Laboratory procedures}

Cores, wedges and cross-sections from the 132 sampled trees were prepared (mounted and sanded), visually dated and cross-dated according to standard dendrochronological methods (Stokes and Smiley, 1968). Tree-rings were measured and the cross-dating was verified using the computer program COFECHA (Holmes, 1983). Some samples could only be dated visually due to the anomalous tree-ring growth of trees affected by avalanches. All samples were carefully checked under a microscope, and details of single tree-ring characteristics were recorded to build the time-frequency distribution of tree-ring signals related to avalanches.

Tree-ring growth signals revealed a variety of responses to disturbances, which could be due to avalanche events: eccentricity, compression wood, abrupt growth changes (releases and suppressions), scars and tree death. Eccentricity is a response to trunk tilting, although trees can also show eccentric tree-rings for other reasons. When conifers are forced to incline or bend, rings develop special characteristics: in the upper side of the trunk, rings become narrower, and in the downslope side rings grow wider. The latter can also form compression wood, which is darker than in normal rings (Timell, 1986). Eccentricity may be detected by statistical analysis of the variation in ring width (Braam and others, 1987), but the simultaneous observation of narrow and wide rings, together with compression wood, is a better technique for obtaining exact dates of avalanches. However, when working with cores it is difficult to assess eccentricity. For this reason, in this study we consider suppression in the upslope samples, release in the downslope ones, and compression wood separately. Abrupt growth changes, release and suppression periods, are sequences of wider and narrower rings, respectively, than the previous ones. A release is usually caused by elimination of competition, while suppression can be due to (i) partial loss of tree crown (breakage of branches or tree trunk), and/or (ii) partial uprooting. Scars are produced by trees as a reaction to wounds from the impact of stones, flowing snow, and branches and trunks of dragged trees carried by the avalanche. Scars were only sampled in young trees. Tree death was dated by crossdating of tree-ring series of dead trees with the master chronology. We have considered sudden tree death when the last rings did not present a reduction in growth rate. A table was constructed with the tree-ring features from 132 dated trees. It contained only the starting year for every signal, and not the complete period during which the signal was observed.

Tree age was estimated by counting whorls along the main axis in young trees. For older trees, ages were estimated counting the rings of the basal samples (usually cores); when the pith was not present, this age was corrected by adding the missing rings to the pith (Bosch and Gutiérrez, 1999). Since basal cores were taken at $0.3 \mathrm{~m}$ from the base, we also added rings from the number of whorls counted in young trees to estimate the final tree age. When cores were sampled higher than $0.3 \mathrm{~m}$ from the base we also added the missing rings to the base. The way we estimated tree age was not accurate (Gutsell and Johnson, 2002), but this was not significant since tree-age class intervals are larger (50 years) than the error in age estimation. We discarded 22 out of 132 dated trees because cores were rotten and age could not be estimated.

\section{RESULTS AND DISGUSSION}

Dendrochronological methodology applied in snow-avalanche studies has three major limitations. The short span of tree-ring series of young trees limits the dating of older events. Other limitations are the general lack of forest in the snow-avalanche run-out area, and that evidence of past events may disappear as a result of later extreme events (Carrara, 1979).

\section{Validation of tree-ring signals from 1996 known avalanche season}

Many of the 132 dated trees (40\%) were affected by 1996 avalanches at Canal del Roc Roig as shown by the different signals in tree-rings. Here we discuss the signals detected from 1996 to 2000 (Fig. 4). External tree morphology observations are not considered in this paper, but some comparisons were made for single trees to better understand some tree-ring responses.

Growth suppression was the most frequent signal in 1996 $(50 \%)$. In some of the samples, the narrowest ring was found to be not in 1996 - the immediate growing season after the events - but in 1997. Some of the trees still presented a suppressed growth rate in 2002. However, other disturbances can cause loss of branches, for instance, snow accumulation on the tree crown (Schweingruber, 1996). This can magnify the amount of signals during avalanche seasons. Compression wood was also very frequent in treerings $(25 \%)$ after 1995 and lasted from 1 to several years. Scars appeared mainly on the upper side of the trunk, but we only sampled five scarred trees.

Near the run-out zone, the series of trunk cross-sections from dead trees showed a sudden tree death after the growing period of 1995. In the upper part of the track, however, the final year of growth (1996) of two dead trees was very narrow. In the case of one tree in the central part of the track, this growth behaviour was due to incomplete uprooting, and the tree survived another year. Even though data are scarce, it can be deduced that the impact of the snow was less severe in the upper part of the track, near the starting zone, than at the end of the track where most of the trees were completely uprooted or broken and sometimes transported.

Tree-age distribution differences exist between trees with and without 1996 signals (Fig. 5a). The proportion of 


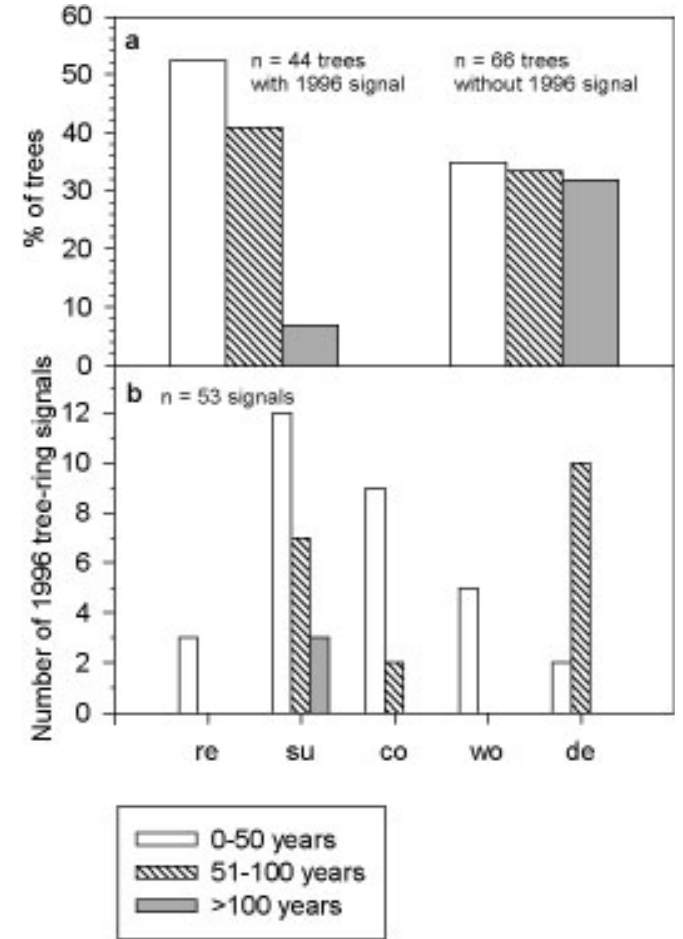

Fig. 5. (a) Age-class distribution for trees with $(n=44)$ and without ( $n=66)$ signal in the 1996 ring. (b) For trees with signals in the 1996 ring, age-class distribution for each type of signal (re, release; su, suppression; co, compression wood; wo, wounds (scars); de, dead trees). Tree-ring signals $(n=53)$ were redundant in some trees.

trees older than 100 years that do not have signals is higher than those with signals. The fact that the avalanche did not affect old trees can be explained by (i) their larger dimen- sions, and (ii) the fact that they do not grow near the path, where snow-avalanche effects are more severe. Only 3 out of 22 trees older than 100 years recorded a response in the 1996 ring and it was suppression (Fig. 5b). Suppression was present in all age classes. Compression wood was more abundant in young individuals ( $0-50$ years), but was also present in trees 50-100 years old (2 out of 44 trees), though not in trees older than 100 years. The age of dead trees ranged from 50 to 100 years, but this could be due to biased sampling; we specifically sampled dead trees near the end of the track, near the run-out zone.

Tree growth responses can show a delay, and tree-ring features may not appear until 1 or more years later (Johnson, 1987). The problem of dating the 1996 avalanche was solved because most of the signals were detected during the immediate growing period of 1996 (40.15\% of tree-ring signals in relation to 132 sampled trees with and without signals), and a smaller proportion during subsequent years (Fig. 4). We found that scars provide a decisive criterion for establishing the exact year, because they are produced by an immediate tree reaction to wounds. For this reason, a higher number of samples should be gathered from scarred trees in future sampling campaigns.

It is important to point out the significance of finding all these signals together because tree-rings can show similar responses to different environmental disturbances. Consequently, only the combination (redundancy) and a high number of these responses reliably confirms past events. Here the evidence of signals from past avalanche events is discussed. Tilting of tree trunks causes eccentricity and provides redundant signals: abrupt growth changes (suppression and release), compression wood or all together. Therefore, the exact year of tilting can be dated, providing reliable information on past events. One of the clearest

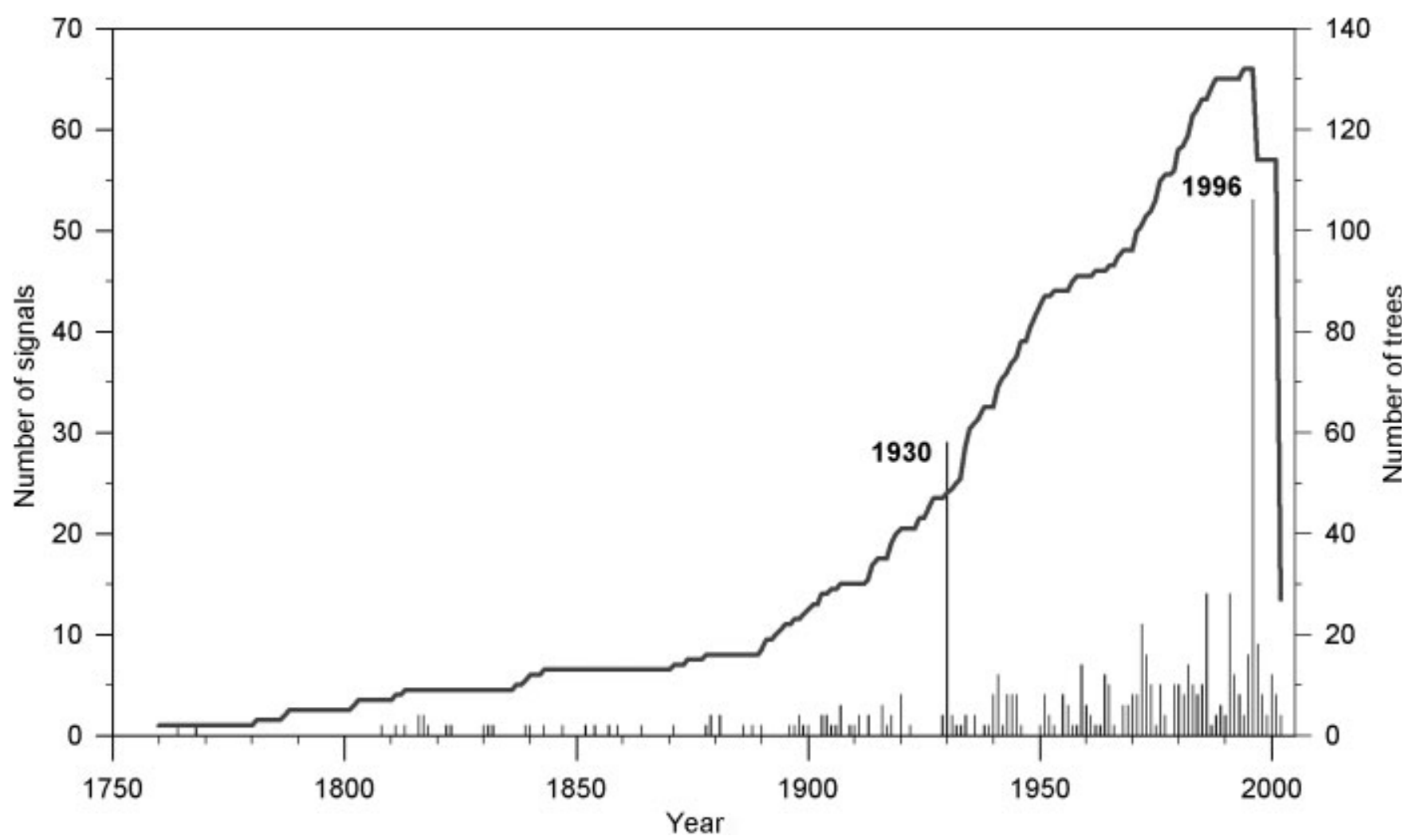

Fig. 6. Yearly frequency distribution of signals detected in tree-ring series susceptible of being caused by avalanche events in Canal del Roc Roig and sample depth (number of trees), 1750-2002. 
signals in tree-rings is sudden tree death, but wood goes rotten and tree-rings become decayed after 50-70 years (Bosch and Gutiérrez, 2001). Near the run-out zone, it was observed that the sapwood of some of the dead trees from 1996 was already rotting, so this source of information about the date and age of dead trees may disappear faster.

\section{Past avalanche events at Canal del Roc Roig}

At present, when snow avalanches reach the railway of Núria tourist resort and damage the line, the train crew documents them, as was done during the winters of 1972 and 1996. These two avalanche seasons were detected after examination of the dendrochronological samples. As explained above, two snow avalanches were documented in 1996. However, it is not possible to distinguish them in treering signals, because tree signals are not different for the two events, as trees only provide annual resolution for avalanche events.

Besides 1996 and 1972, three other feasible avalanche years were detected by a high frequency of signals: 1991, 1986 and 1930 (Fig. 6). There is no historical evidence for these possible events. These should be checked in future campaigns to verify their occurrence. Other possible avalanche events before 1930 could not be corroborated because samples were scarce and results not reliable, even though tree-ring signals were registered up to the mid-18th century (Fig. 6).

The amount of signals dated for 1930 and their spatial distribution (Fig. 2) point to a large avalanche. Pines affected during winter 1930 occupy a broader area in the starting zone than those affected during 1996. This would mean a larger amount of snow collapsing downslope than during the 1996 events. The starting zone was also different: signals belonging to 1996 are not detected on the hydrographical right side of the path, while signals linked to 1930 are abundant on this side. The hypothesis that a large avalanche occurred in 1930 is quite probable, as these forests have not been managed and few of the sampled dead trees were 70 years old. Snow avalanches do not always run through the full extent of their tracks and flow out over the run-out zone. Small avalanche events are more frequent (Carrara, 1979). It is interesting to note the variety of trajectories that snow avalanches can have along the same path. In Figure 2, dead trees about 70 years old caused by the February 1996 events were abundant on the righthand side in a forested area near the run-out zone. This place is some metres above the central part of the track section, and trees had not been destroyed during the 1972 event. The establishment of trees in this area probably took place mainly after 1930; some of them were small and so they could have survived this event. Therefore, the hypothesis could be that the 1930 avalanche destroyed trees growing there, and this avalanche could have had a similar trajectory to that of 1996. Further research must be undertaken on this topic.

This study was also useful in corroborating the mapped avalanche limits edited in the avalanche-paths map (ICG, 2002) by the location of all the trees with signals from different past avalanche events (Fig. 2). For instance, the boundaries described in the map in the run-out zone on the other side of the railway track precisely coincide with those found by dendrochronological means (see Molina and others, 2004). But in other areas, as in the starting zone, some discrepancies exist. So from the avalanche signals in tree-rings, cartography can be improved.

\section{GONGLUSIONS}

The 1996 avalanche season was clearly detected in treerings: $40 \%$ of the sampled trees (53 out of 132) had tree-ring signals related to the avalanche. These allowed us to determine past avalanche events in Canal del Roc Roig. Of the past events probably related to another large avalanche, the one in 1930 stood out for its high frequency of signals, $60 \%$ (29 out of 48 trees).

Tree-rings can show a variety of signals due to avalanche effects. Avalanches can be dated accurately if enough adequate samples are taken. The combination (redundancy) of signals is important for ascertaining an avalanche season. From the tree-ring signals frequency for 1996, it was clear that scars and sudden tree death were a decisive criterion for establishing the exact year of the avalanche event.

In this study, trees showed different responses to the avalanche events, depending on their age. The few older trees affected by the 1996 avalanche reacted with suppressed growth; tree mortality occurred among trees 50-100 years old. The youngest trees, up to 50 years old, showed abrupt growth changes and compression wood.

Dendrochronology proved to be a good tool for estimating the frequency of avalanche events, but the results have to be treated carefully. It was observed that it is not possible to detect two events from the same winter season, as occurred during 1996 at Canal del Roc Roig, because tree-rings provide the same type of signals.

Besides the 1996 events, tree-rings also showed a significative number of signals for the 1972 documented snow avalanche. It is likely that three other avalanches occurred at this site that were not previously documented. A hypothesis for the 1930 event will have to be investigated in the future. The starting zone of the 1930 avalanche event seemed to be larger than the 1996 one, and affected mainly the southern side of the avalanche path. The hints provided in this study indicate that the 1930 event could have been of a higher magnitude than the 1996 one, and that this last episode would not be so extraordinary. Dendrochronology has proved useful for determining avalanche-path limits with more accuracy.

\section{ACKNOWLEDGEMENTS}

We wish to thank Vall de Núria tourist facilities personnel; the Dendrix Research Group, especially O. Planells; and L. Daniels for her thorough and respectful revision of the manuscript which substantially improved it. The Spanish Ministry of Science and Technology and the European funding agency FEDER fund the Aludex project, "Caracterización de aludes catastróficos a través del estudio dendrocronológico y nivo-climático", reference No. REN200202768/RIES

\section{REFERENCES}

Bosch, O. and E. Gutiérrez. 1999. La sucesión en los bosques de Pinus uncinata del Pirineo. De los anillos de crecimiento a la historia del bosque. Ecologia 13, 133-171.

Bosch, O. and E. Gutiérrez. 2001. La mortalitat del pi negre (Pinus uncinata, Ram.): Causes, taxes i permanència dels arbres morts, a través de l'anàlisi dels anells de creixement. In V Fornades sobre recerca al Parc Nacional. La investigació al Parc Nacional d'Aigüestortes i Estany de Sant Maurici. Barcelona, Generalitat de Catalunya, 123-139. 
Braam, R. R., E. J. J. Weiss and P. A. Burrough. 1987. Spatial and temporal analysis of mass movement using dendrochronology. Catena, 14(6), 573584.

Butler, D. R. 1979. Snow avalanche path terrain and vegetation, Glacier National Park, Montana. Arct. Alp. Res., 11 (1), 17-32.

Carrara, P.E. 1979. The determination of snow avalanche frequency through tree-ring analysis and historical records at Ophir, Colorado. Geol. Soc. Am. Bull., 90 (1), 773-780.

Cook, E. R. and L. A. Kairiukstis, eds.. 1990. Methods of dendrochronology: applications in the environmental sciences. Boston, MA, Kluwer Academic Publishers.

García, C., J. Gavaldà, G. Martí, P. Martínez and P. Oller. 2000. Butlleti nivològic $i$ d'allaus. Hivem 95/96. Barcelona, Servei Geològic de Catalunya. Institut Cartogràfic de Catalunya.

Gutsell, S. L. and E. A. Johnson. 2002. Accurately ageing trees and examining their height-growth rates: implications for interpreting forest dynamics. 7. Ecol., 90, 153-166.

Holmes, R. L. 1983. Computer-assisted quality control in tree-ring dating and measurement. Tree-Ring Bull., 43(1), 69-78.

Institut Cartogràfic de Catalunya (ICG). 2000. Núria-Freser. (Scale 1: 25 000.) Barcelona, Servei Geològic de Catalunya. Institut Cartogràfic de Catalunya. (Mapa de zones d'allaus de Catalunya.)

Institut Cartogràfic de Catalunya (ICG). 2002. Conveni de seguiment geològic de ta traça del Ferrocarril de Cremallera de Ribes-Núria. Informe sobre les allaus de neu. Ia fase. Barcelona, Servei Geològic de Catalunya. Institut Cartogràfic de Catalunya.
Johnson, E. A. 1987. The relative importance of snow avalanche disturbance and thinning on canopy plant populations. Ecology, 68(1), 43-53.

McClung, D. M. and P. A. Schaerer. 1993. The avalanche handbook. Seattle, WA, The Mountaineers.

Molina, R., E. Muntán, L. Andreu, G. Furdada, P. Oller, E. Gutiérrez, P. Martínez and J. M. Vilaplana. 2004. Using vegetation to characterize the avalanche path of Canal del Roc Roig, Vall de Núria (Eastern Pyrenees, Spain). Annals of Glaciology, 38.

Pelfini, M., M. Santilli, M. Caccianiga and F. Gironi. 2001. Un diverso approccio per lo studio delle valanghe. Dendrocronologia e fitosociologia. Neve e Valanghe 44, 10-16.

Potter, N., Jr. 1969. Tree-ring dating of snow avalanche tracks and the geomorphic activity of avalanches, northern Absaroka Mountains, Wyoming. In Schumm, S. A. and W. C. Bradley, eds. United States contributions to Quaternary research: papers presented on the occasion of the VIII Congress of the International Association for Quaternary Research, Paris, France, 1969. Boulder, CO, Geological Society of America, 141-165. (Special Paper 123.)

Schweingruber, F. H. 1996. Influence of snow. In Schweingruber, F. H. ed. Tree rings and environment. Dendroecology. Berne, Paul Haupt Verlag. Swiss Federal Institute for Forest, Snow and Landscape Research, Birmensdorf, 183-196.

Shroder, J. F., Jr. 1978. Dendrogeomorphical analysis of mass movement of Table Cliffs Plateau, Utah. Quat. Res., 9, 168-185.

Stokes, M. A. and T. L. Smiley. 1968. An introduction to tree-ring dating. Chicago, IL, University of Chicago Press.

Timell, T. E. 1986. Compression wood in Gimnosperms. Berlin, Springer-Verlag. 